Scientific journal

PHYSICAL AND MATHEMATICAL EDUCATION

Has been issued since 2013.

Науковий журнал

ФІЗИКО-МАТЕМАТИЧНА ОСВІТА

Видається з 2013.
ISSN 2413-158X (online)

ISSN 2413-1571 (print)

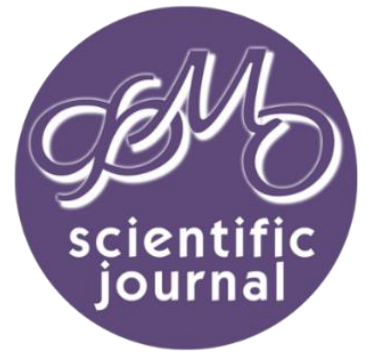

\title{
http://fmo-journal.fizmatsspu.sumy.ua/
}

Друшляк М.Г. Словник візуальної освіти: графічна культура, візуальна культура. Фізико-математична освіта. 2019. Випуск 4(22). С. 36-44.

Drushlyak M. Glossary of "visual" education: graphical culture, visual culture. Physical and Mathematical Education. 2019. Issue 4(22). P. 36-44.

DOI 10.31110/2413-1571-2019-022-4-006

УДК 378.14: 371.214 .46

М.Г. Друшляк

Сумський державний педагогічний університет імені А.С.Макаренка, Україна marydru@fizmatsspu.sumy.ua ORCID: 000-0002-9648-2248

\section{СЛОВНИК ВІЗУАЛЬНОЇ ОСВІТИ: ГРАФІЧНА КУЛЬТУРА, ВІЗУАЛЬНА КУЛЬТУРА}

\section{АНОТАЦІЯ}

Формулювання проблеми. В умовах посилення візуальної комунікації у сучасному суспільстві формується нова культура сприйняття інформачії - переважно у візуальній формі. Збільшення візуальної складової призводить до впровадження терміну «візуальний» у освітню галузь. Відбувається оновлення ї поняттєво-термінологічного апарату $i$ спостерігається дисонанс, пов'язаний із змістом категорій «візуальної» освіти.

Матеріали і методи. Аналіз науково-педагогічних джерел для визначення змістового наповнення понять "графічна культура», «інтелектуально-графічна культура», «візуальна культура».

Результати. Графічна та візуальна культура - це певний рівень досконалості в оволодінні діяльністю, яка пов'язана певною мірою з різними типами інформації: графічною (за формою представлення) - це інформація у вигляді зображень, таблиць, схем, графіків, або візуальною (за способом сприйняття) - че інформація, що сприймається органами зору. Графічна культура - це інтегративна якість особистості, яка характеризується високим рівнем сформованості графічних знань, умінь та навичок, готовністю використовувати їх у професійній діяльності, здатності відтворювати, зберігати та передавати графічними засобами різноманітну інформацію, передбачає здатність до аналізу, прогнозування, рефлексії професійної діяльності та забезпечує професійний творчий саморозвиток, самовдосконалення й підвищення фахового рівня. Інтелектуально-графічна культура - це сукупність знань, умінь, цінностей та уявлень, що дозволяють не тільки засвоювати одиниці навчального матеріалу через наочно-образні (візуальні) моделі знань, а і самостійно їх проектувати, використовуючи в рівній мірі як логічні, так $і$ художні можливості. Візуальна культура - це інтегративна якість особистості, яка характеризується високим рівнем візуальних знань, умінь та навичок (здатність сприймати, розпізнавати, аналізувати, інтерпретувати, оцінювати, співставляти, представляти та створювати власні візуальні образи), готовністю використовувати їх у професійній діяльності.

Висновки. Результати даного дослідження дають можливість із наповненням і співвідношенням понять “графічна культура» та «візуальна культура», оскільки у науковій літературі трактування цих понять різнорідні і не завжди аргументовані.

КлючОВІ СлОВА: словник «візуальної» освіти, культура, графічна культура, інтелектуально-графічна культура, візуальна культура.

\section{ВСТУП}

Постановка проблеми. Сьогодні формується нова культура сприйняття інформації переважно у візуальній формі як реакція на розширення і різнобарв'я інформаційних потоків (Белоусова\&Житенева, 2014). На зміну «лінгвістичному повороту» приходить «візуальний поворот», що характеризується посиленням візуальної комунікації (Rоrty, 1992). збільшення візуальної складової у всіх сферах життя людини призводить до зміни сприйняття інформації, що характеризується здатністю швидко реагувати на різні змістові фрагменти, формати даних, їх обсяг, тяжінням до образних (візуальних) каналів подання інформації, і поряд з цим, непристосованістю молоді до сприйняття лінійного та однорідного інформаційного контенту. Іконічні знаки отримують самостійне існування, а їх візуальна оболонка не потребує вербального пояснення. Такий процес у оточенні людини призводить до відторгнення вербального, людина перебуває у суспільстві у стані окуляроцентризму (Мартін Джей (Martin, 1993), де візуальній інформації надається перевага. Сучасна культура є візуальноцентрованою. Вона в тій чи іншій мірі витісняє текстову і призводить до того, що людина починає мислити по-іншому. 
У зв'язку з цим термін «візуальний» впроваджується у різні сфери життя людини, і освіта не $\epsilon$ винятком. Відбувається оновлення іï поняттєво-термінологічного апарату, з'являються терміни «графічна культура», «інтелектуально-графічна культура», «візуальна культура». Науковці майже завжди у своїх дослідженнях пропонують авторські варіанти формулювань цих понять, які не завжди аргументовані і узгоджуються між собою. У науковій та методичні літературі спостерігається понятійний дисонанс: автори часто ототожнюють поняття «грамотність», «компетентність» та «культура» та дотримуються різного ієрархічного впорядкування цих понять. Тому досліднику, який починає свої пошуки у рамках зазначеної тематики, важко розібратися із змістом категорій «візуальної» освіти.

Отже, вважаємо, що в рамках формування словника «візуальної» освіти потрібно проаналізувати такі категорії як «графічна культура», «інтелектуально-графічна культура», «візуальна культура» і розібратися з їх наповненням та співвідношенням. Зауважимо, що ми вже зверталися до цієї проблематики і аналізували зміст та співвідношення таких категорій як «наочність», «візуалізація», «візуальне мислення» (Друшляк, 2018), «графічна грамотність», «візуальна грамотність» (Друшляк, 2019b), «графічна компетентність», «візуальна компетентність» (Друшляк, 2019а).

У своєму дослідженні будемо дотримуватись структурного ланцюга результативності освіти, запропонованого Б. С. Гершунським: «грамотність» - «освіченість» - «компетентність» - «культура» - «менталітет» (Гершунский, 2003). Це ієрархічні освітні сходи сходження людини до все більш високих освітніх результатів, де культура мислиться як вищий ступінь прояву людської освіченості.

Метою статті $€$ аналіз понять «культура», «графічна культура», «інтелектуально-графічна культура», «візуальна культура» за тлумаченнями вітчизняних та зарубіжних дослідників.

\section{МЕТОДИ ДОСЛІДЖЕННЯ}

Термінологічний аналіз науково-педагогічних джерел для визначення змістового наповнення понять «графічна культура», «інтелектуально-графічна культура», «візуальна культура», «візуально-графічна культура».

\section{РЕЗУЛЬТАТИ}

Графічна культура - це інтегративна якість особистості, яка характеризується високим рівнем сформованості графічних знань, умінь та навичок, готовністю використовувати їх у професійній діяльності, здатності відтворювати, зберігати та передавати графічними засобами різноманітну інформацію, передбачає здатність до аналізу, прогнозування, рефлексії професійної діяльності та забезпечує професійний творчий саморозвиток, самовдосконалення й підвищення фахового рівня.

Інтелектуально-графічна культура - це сукупність знань, умінь, цінностей та уявлень, що дозволяють не тільки засвоювати одиниці навчального матеріалу через наочно-образні (візуальні) моделі знань, а і самостійно їх проектувати, використовуючи в рівній мірі як логічні, так і художні можливості.

Термінологічні словники з педагогіки не дають визначення візуальної культури і педагогічна теорія до теперішнього часу не розглядає це поняття, оскільки візуальну культуру відносять до категорій культурології. Вектор пропонованого дослідження вимагає визначення візуальної культури як інтегративної якості особистості, яка характеризується високим рівнем візуальних знань, умінь та навичок (здатність сприймати, розпізнавати, аналізувати, інтерпретувати, оцінювати, співставляти, представляти та створювати власні візуальні образи), готовністю використовувати їх у професійній діяльності.

Графічна та візуальна культура - це певний рівень досконалості в оволодінні діяльністю, яка пов'язана тією чи іншою мірою з різними типами інформації: графічною (за формою представлення) - це інформація у вигляді зображень, таблиць, схем, графіків, або візуальною (за способом сприйняття) - це інформація, що сприймається органами зору.

\section{ОБГОВОРЕННЯ}

Спільною основою понять «графічна культура», «інтелектуально-графічна культура» та «візуальна культура» $\epsilon$ поняття «культура».

\section{1. Культура}

Поняття «культура» в сучасній науковій літературі має надзвичайно велике число тлумачень. Вивчаючи різні сторони і прояви культури, дослідники часто по-різному визначають саме поняття, причому ці розбіжності існують не тільки у представників окремих наук, а й у філософів. А. І. Арнольдов (Арнольдов, 1993) відзначає, що в даний час в науковий обіг введено понад 250 різних дефініцій поняття «культура».

Поняття "культура" (від латинського “cultura" - обробка) вживається, як правило, в значенні обробки, землеробства. Ще Цицерон говорить про те, що розум необхідно обробляти також, як селянин обробляє землю. “Обробка розуму", удосконалення власного духу є істинне покликання вільної людини... (Цицерон, 1985). За Цицероном культура це ступінь досконалості, досягнутий в оволодінні тією або іншою галуззю знань та діяльності.

Філософське розуміння культури наступне: культура $\epsilon$ все, що створене людиною, «штучне середовище», що служить задоволенню різноманітних потреб людини і його розвитку. У культурі виражається «міра оволодіння людиною силами природи, суспільними відносинами, своєю власною природою» (Ефимов\&Громов,1989). У «Новій філософській енциклопедії» культура формулюється як «система надбіологічних програм людської життєдіяльності, що історично розвивається (діяльності, поведінки і спілкування), що забезпечує відтворення і зміни соціального життя в усіх його основних проявах» (Новая философская энциклопедия, 2001).

У словнику іноземних слів значення культури трактується як "ступінь суспільного і розумового розвитку, властивий будь-кому" (Энциклопедический словарь, 1954). А ось у слов'янських мовах слово «освіта» широко вживалося як синонім «культури» (Лисюткин, 1982).

У Тлумачному словнику В. Даля (Даль, 1989) культура трактується як «обробка і догляд, обробка; утворення розумове і моральне». 
У соціологічному енциклопедичному словнику культура (від лат. cultura - оброблення, виховання, освіта, розвиток, шанування) трактується, як: 1) сукупність матеріальних і духовних цінностей, що виражає певний рівень історичного розвитку даного суспільства та людини; 2) сфера духовної життєдіяльності суспільства, що охоплює систему освіти, виховання, духовної творчості; 3) рівень оволодіння тією або іншою галуззю знань або життєіяльності; 4) форми соціальної поведінки людини, що зумовлені рівнем їі виховання та освіти (Социологический энциклопедический словарь, 1998).

У суспільстві немає явищ, які не можна було $б$ розглядати як ті, що не відносяться до культури. Культурологічна точка зору задає певну пізнавальну установку, яка спрямована на дослідження можливостей різних сфер життя в справі розвитку людини як суб'єкта діяльності.

У словнику з культурології культура розуміється як «історично визначений рівень розвитку суспільства, творчих сил і здібностей людини, виражений у типах і формах організації життя та діяльності людей, в їхніх взаємовідносинах, а також у створюваних ними матеріальних і духовних цінностях» При цьому культура "включає в себе предметні результати діяльності людей, а також людські сили і здібності, реалізовані в діяльності (знання, уміння, навички, рівень інтелекту, морального й естетичного розвитку, світогляд, способи і форми спілкування людей)» (Культура и культурология, 2003.)

Психологічна енциклопедія розглядає культуру в широкому розумінні як «усе те, що створене, зроблене людиною, на що вона наклала відбиток своєї діяльності» (Психологічна енциклопедія, 2006).

В Українському педагогічному словнику культура (від лат. cultura - виховання, освіта, розвиток) - це сукупність практичних, матеріальних і духовних надбань суспільства, які відображають історично досягнутий рівень розвитку суспільства й людини і втілюються в результатах продуктивної діяльності» (Гончаренко, 1997).

Але існують і інші трактування поняття "культура", наприклад, культура як сукупність досягнень суспільства в галузі освіти, мистецтва, науки та інших галузях духовного життя; вміння використовувати історично накопичені знання і практичний досвід для підкорення сил природи, для зростання виробництва, для вирішення суспільного розвитку.

Л. Н. Коган відзначає, що не будь-яка людська діяльність розвиває і збагачує культуру, а лише та, в результаті якої утворюються нові зразки й цінності матеріального і духовного життя, в результаті якої розвивається і змінюється сама людина (Коган, 1972).

Як вважає педагог В. О. Куріна, культура є процесом людської діяльності, що опредмечується в її результатах. При цьому мається на увазі не вся діяльність людей, а лише творча діяльність, спрямована на перетворення світу і природи, суспільних відносин і самої людини. Дійсно, будь-яка культура передбачає діяльність суспільну або індивідуальну, але не всіляку діяльність можна трактувати як культурну, а лише той спосіб діяльності, що передбачає наявність позитивних перетворень в економічній, соціальній, духовній сферах суспільства (Курина, 1997).

Важливим фактором культури є особистість, яка визначає їі функціонування та є її носієм. 3 одного боку, культура формує той чи інший тип особистості, культура є завжди проявом певного рівня розвитку особистості, а 3 іншого особистість вносить до норм, потреб і поведінкових зразків свої вимоги та інтереси.

Культура - це особлива сфера і форма діяльності, що має свій зміст і свою структуру, а разом з тим впливає на різні сфери буття. Культура формує духовний світ суспільства і людини, забезпечує суспільство в цілому диференційованою системою знань та орієнтацій, необхідних для здійснення всіх видів діяльності, що існують в суспільстві, у тому числі педагогічної.

І це лише невелика частка існуючих на даний момент дефініцій поняття "культура», які в різні часи намагалися систематизувати деякі науковці. Так, одна з популярніших систематизацій визначень культури - це систематизація, запропонована американськими науковцями А. Кребером і К. Клакхоном (Кребер\&Клакхон, 1992), які подали понад 150 відомих на той час визначень та концепцій культури. Ними пропонуються наступні типи означень поняття «культура»: 1) описові визначення, в яких перераховується все те, що охоплює поняття күльтури; 2) історичні визначення, в яких акцентуються процеси соціального наслідування, традиції; 3) нормативні визначення, що підкреслюють роль цінностей норм; 4) психологічні визначення, які роблять акцент на процеси адаптації до середовища, навчання; 5) структурні визначення, що акцентують увагу на структурі культури; 6) генетичні визначення, в яких культура визначається з позиції їі походження.

Іншу типологію визначень культури запропонував Л. Кертман, який вважає, що вся багатоманітність дефінітивних пропозицій розподіляється між антропологічним, соціологічним і філософським підходами. На його думку, антропологічний підхід ґрунтується на визнанні унікальності, неповторності та рівноцінності всіх конкретно-історичних і національних форм культури (А. Бернард: А. Кребер, К. Даусон). Соціологічні визначення, за Л. Кертманом, зосереджують увагу на факторах організації й формування життя певного суспільства (В. Бекет, Б. Маліновський) (Каган, 1997). Філософські ж визначення роблять наголос на аналізі певних рис, характеристик, закономірностей у житті суспільства, які складають фундамент культури й визначають причину й напрям їі розвитку (Г. Беккер, Г. Зіммель). Проте кожен із виділених як А. Кребером і К. Клакхоном, так і Л. Кертманом типів визначень зосереджується, як правило, на одному певному аспекті культури, i, власне, вони не заперечують, а скоріше доповнюють один одного (Гомонюк, 2012).

Що ж стосується поділу культури за їі видами, то у вітчизняній культурології поки ще немає єдиних загальноприйнятих принципів такого поділу. Одні вчені здійснюють виділення видів культури згідно з видами людської діяльності (економічна, політична, педагогічна, професійна). Інші до виділення видів культури беруть за основу певні соціальні громади (культура учнів, студентів, лікарів, вчителів, інженерів).

Ми погоджуємося з позицією, що найбільш суттєвими рисами поняття «культура» $є$ певний рівень досконалості в оволодінні діяльністю; глибоке, свідоме, поважне ставлення до спадщини минулого; володіння теоретичними знаннями, вміннями, навичками та готовність їх використання у практичній діяльності; здатність до творчого сприйняття та розуміння, творчого перетворення дійсності; готовність саморозвитку. У даному дослідженні розглядаємо культуру через призму освітньої галузі, а тому вважаємо, що культура - це найвищий прояв розвитку особистості у певній галузі.

\section{2. Графічна культура}

Рівнем результативності освіти, інтегральним показником творчого початку професійної діяльності $\epsilon$ культура фахівця, що складається в єдності та взаємодії складових, однією з яких є професійна графічна культура. 
Предметна спрямованість досліджень графічної культури зосереджена на підготовці вчителів трудового навчання, креслення, інженерів, конструкторів-модел'єрів. Вважається, що основними графічними дисциплінами $€$ нарисна геометрія, інженерна та комп'ютерна графіка, вони і забезпечують фундамент графічної професійної діяльності.

Зміст поняття «графічна культура» базується на графічних знаннях - це результат сприйняття, усвідомлення й узагальнення геометричних, креслярсько-графічних та інших понять, елементів графічної мови у процесі навчальнопізнавальної та виробничо-практичної діяльності людини, що $є$ достатньою теоретичною основою для успішного розв'язання графічних задач (Нищак, 2014). На основі графічних знань формуються графічні вміння. Вміння передбачає екстеріоризацію - втілення знань у фізичну дію. Графічні вміння - це свідоме володіння системою практичних дій, необхідних для цілеспрямованої графічної діяльності. При цьому система практичних дій передбачає відбір необхідних знань, виділення суттєвих властивостей, практичне перетворення (застосування) знань, контроль і коригування результатів діяльності та ін. Уміння, що передбачає усвідомлене виконання дії, може перерости у навичку, яка характеризується частковою "автоматизованістю" виконання і регуляції дії. Графічні навички - це вдосконалені вміння графічної діяльності, що реалізуються на рівні несвідомого контролю й забезпечують досягнення найкращого результату з найменшим розумовим напруженням.

Більш широке тлумачення надає П. Г. Буянов, у якого графічна культура - це здатність людини до створення і засвоєння графічних способів відображення, зберігання та передачі інформації про оточуючу дійсність. Це вищий рівень результативності графічної підготовки, це не тільки початкові графічні знання, а і всебічне оволодіння та творче осмислення способів їх реалізації у професійній діяльності (Буянов, 2008).

В. О. Потієнко та Ю. О. Дорошенко (Потієнко\&Дорошенко, 2012) стверджують, що графічна культура є сукупністю особистих досягнень людини в галузі засвоєння графічних методів, засобів і технологій перетворення і застосування інформації у процесі навчальної, виробничої та творчої діяльності.

Важливим показником сформованості графічної культури, на думку В. К. Сидоренка (Сидоренко, Голіяд, Кулик та ін., 2009), має стати прагнення та здатність до використання графічної інформації в навчальних та практичних ситуаціях. При цьому важливе місце вчений відводить рівню сформованості графічних знань і вмінь, які можуть виступати засобом нового пізнання. У більш широкому трактуванні графічна культура має відображати готовність людини до планування, коригування та прогнозування своїх дій, побудови процесу діяльності в образах з наступним його втіленням в реальні дії чи процеси.

М.В.Лагунова, Т.В.Чемоданова, І.Д.Нищак досліджували інженерно-графічну культуру. Так, М. В. Лагунова (Лагунова, 2001) під графічною культурою інженера (інженерно-графічною культурою) розуміє вияв сформованості і розвитку якостей особистості, що реалізуються у професійній діяльності (графічній кругозір, спеціальний тезаурус графічних понять та ін.); високу продуктивність діяльності, що базується на системі графічних умінь і навичок; належний рівень просторового мислення, що уможливлює процес сприйняття, структурування й декодування графічної інформації професійного характеру.

На думку Т. В. Чемоданової (Чемоданова, 2004) інженерно-графічна культура - це професійно важлива якість особистості, яка формується у процесі інженерно-графічної підготовки і розвивається протягом подальшого здійснення професійної діяльності, пов'язаної з постійним використанням знань, умінь, засобів і методів інженерної графіки і комп'ютерного проектування.

І. Д. Нищак інженерно-графічну культуру вчителя технологій окреслює як інтегральну характеристику професійноособистісних якостей педагога, що відображає високий рівень знань, умінь і навичок та практичного досвіду, необхідних для успішного розв'язання професійних інженерно-графічних задач; здатність до рефлексії власної інженерно-графічної діяльності, самовдосконалення й підвищення фахового рівня (Нищак, 2015).

О.М. Джеджула аналізує співвідношення між поняттями «графічна компетентність» і «графічна культура». Дослідник стверджує, що між цими поняттями існує безумовний зв'язок та певна ієрархічна підпорядкованість. «Графічна культура», на думку О.М.Джеджула, є більш широким поняттям, ніж «графічна компетентність». «Говорячи про професійну компетентність інженера, ми повинні орієнтуватись на графічну культуру як основу високоефективної професійної діяльності. Графічну культуру не правомірно ототожнювати з умінням відтворювати, зберігати та передавати графічними засобами різноманітну інформацію про предмети, процеси та явища, читати та виконувати конструкторськотехнологічну документацію. Це поняття ми вважаємо комплексним, яке дозволяє реалізувати такі способи діяльності та світогляд, результатом яких буде не лише ефективна інженерна графічна діяльність, але й сформована мотивація до інновацій та «інженерна відповідальність», що відповідає концепції сталого розвитку суспільства» (Джеджула, 2018).

А.А. Ляміна, досліджуючи формування графічної культури у майбутніх конструкторів-моделєрів, наводить наступне означення. Графічна культура - це інтегративна якість, яка характеризується єдністю графічних знань, умінь та навиків, цінносного відношення до результатів графічної діяльності і забезпечує професійний творчий саморозвиток майбутнього спеціаліста (Лямина, 2007).

Л. В. Брикова пропонує наступне уточнене визначення: графічна культура випускника технічного вузу - це базова, інтегральна якість особистості, що проявляється у високому рівні всіх видів і форм знань, у здатності до аналізу та прогнозування виробничого процесу, в використанні геометро-графічних знань для ефективного вирішення професійних завдань, а також в усвідомленні цінності графічної підготовки для професійного майбутнього (Брыкова, 2011).

Як ми бачимо, термін «графічна культура» зустрічається в педагогічній та науково-дослідницької літературі в різних контекстах. Проведений аналіз різних підходів до визначення феномена професійної графічної культури дозволяє сформулювати наступне означення.

Графрічна культура - че інтегративна якість особистості, яка характеризується високим рівнем сформованості графічних знань, умінь та навичок, готовністю використовувати їх у професійній діяльності, здатності відтворювати, зберігати та передавати графічними засобами різноманітну інформацію, передбачає здатність до аналізу, прогнозування, реслексії професійної діяльності та забезпечує професійний творчий саморозвиток, самовдосконалення й підвищення фахового рівня. 


\section{3. Інтелектуально-графічна культура}

С. В. Аранова характеризує інтелектуально-графрічну культуру як сукупність знань, умінь, цінностей та уявлень, що дозволяють не тільки засвоювати одиниці навчального матеріалу через наочно-образні (візуальні) моделі знань, а і самостійно їх проектувати, використовуючи в рівній мірі як логічні, так і художні можливості (Аранова, 2017). Дослідниця наголошує, що інтелектуально-графічна культура формується тільки у результаті об'єднання художніх та логічних можливостей, що впливає на здатність суб'єкта переносити художньо-логічні прийоми на візуально-графічні методи розв'язування задач різних галузей знань. При цьому не останню роль відіграє шкільна дисципліна «образотворче мистецтво», оскільки в ході формування інтелектуально-графічної культури повинні використовуватися основи художньої грамоти, вміння будувати композицію, встановлювати масштабні співвідношення та пропорції, використовувати акцент, ритм, симетрію і асиметрію у зображенні тощо (Аранова, 2011). Модель інтеграції художнього та логічного утворює сферу інтелектуально-графічної культури.

Основним продуктом інтелектуально-графічної культури і результатом інтеграції раціонально-логічної та емоційно-художньої складових є побудова деякої візуально-інформаційної моделі, під якої С. В. Аранова розуміє систему взаємопов'язаних змістових елементів, що відновлює у наочній формі суттєві властивості навчального тексту. Візуальноінформаційна модель - це не просто схематичний виклад матеріалу, це елемент комунікації, це текст, поданий зрозумілою для всіх мовою з дотриманням критеріїв, які встановлені залежно від педагогічної мети та можливостей реципієнта.

Автор також наголошує на необхідності використання засобів комп'ютерної візуалізації знань. Але разом з цим відкидає думку про ототожнення візуалізації навчального матеріалу з комп'ютерними технологіями, наполягаючи на візуальному представленні інформації і в рукотворному графічному виконанні.

\section{4. Візуальна культура}

Термін «візуальна культура» виник у другій половині XX ст. у роботах європейських та американських вчених як міждисциплінарне поле досліджень. В.П. Зінченко відзначає, що з появою великої кількості нових і достатньо різноманітних засобів візуальної комунікації, значним розширенням предметного світу, гостро постає проблема формування візуальної культури, яка становить невід'ємну частину культури сучасної людини (Зинченко, 1998).

Н.В. Дубова розуміє візуальну культуру як частину поняття «культура», яка розвиває здібності сприйняття візуальних образів, уміння їх аналізувати, інтерпретувати, оцінювати, співставляти, представляти, створювати на цій основі власні образи. Візуальна культура не $\epsilon$ герметичною самодостатньою сферою, вона постійно вбирає в себе додаткову інформацію, пов'язану з розвитком технічного прогресу, з осягненням нових горизонтів людського пізнання. Візуальна культура - це новий міждисциплінарний напрям, який виник на перетині філософії, теорії культури, соціології та мистецтвознавства (Дубовая, 2010).

Н. В. Сирова та В. Н. Чикишев мислять візуальну культура як академічне поле дослідження, яке включає в себе деякі комбінації культурології, історії мистецтва, критичної теорії, філософії, антропології і фокусується на зорових образах. Вони наголошують на необхідності формування високого рівня візуальної культури суб'єкта, що полягає у вмінні візуалізувати інформацію, критично до неї відноситися і використовувати ії, ретельно відбираючи необхідне і якісне (Сырова\&Чикишев, 2018).

О. М. Моргун розуміє візуальну культуру, виходячи з методологічного підходу, як деякий комплекс візуальномисленних відношень суб'єкта до реальності, а також конкретно-зорові образи його (суб'єкта) креативної поведінки. Візуальний об'єкт мислиться як візуальний образ і зображення, що має автономний зміст і значення (Моргун, 2010).

О. В. Мехоношина вважає, що візуальна культура - це художньо-комунікативна система, яку можна розглядати на двох рівнях: соціально-естетичному як сукупність цінностей, що сприймаються і включають багаторівневу знакову систему, що моделює у візуальних образах картину світу; та особистісному як систему естетичної взаємодії людини з візуальними образами, їх сприйняття, проекція на особистісний досвід, оцінка, пробудження асоціацій, здібність до створення візуальних образів (Мехоношина, 2011).

У розумінні С. С. Зоріна та Л. К. Веретеннікової візуальна культура - це багаторівнева культура зорового сприйняття, переробки і відображення візуальної інформації (Зорин\&Веретенникова, 2002).

Як ми бачимо, візуальна культура має відношення швидше до професійної художньої сфери і лежить у площині сучасних художніх практик, використовується в основному в середовищі культурологів, а педагогічна теорія до теперішнього часу термін «візуальна культура» не асимілювала. Педагогічні словники та термінологічні словники 3 педагогіки останніх років не дають визначення візуальної культури, а педагоги-практики, використовуючи його для опису стану сучасного суспільства, посилаються на культурологічні дослідження, «визнаючи, що термін візуальна культура використовується в педагогіці мистецтва достатньо широко, а сучасні гуманітарні науки (і педагогіка в тому числі) переосмислюють цей термін, визначаючи його як кросс-дисциплінарне поле досліджень" (Paul, 2002).

Орієнтація на освітню галузь вимагає визначення візуальної культури як інтегративної якості особистості, яка характеризується високим рівнем візуальних знань, умінь та навичок (здатність сприймати, розпізнавати, аналізувати, інтерпретувати, оцінювати, співставляти, представляти та створювати власні візуальні образи), готовністю використовувати їх у професійній діяльності.

\section{вИСновки}

Таким чином, можна стверджувати наступне.

1. Сьогодні формується нова культура сприйняття інформації переважно у візуальній формі як реакція на розширення і різнобарв'я інформаційних потоків. На зміну «лінгвістичному повороту» приходить "візуальний поворот», що характеризується посиленням візуальної комунікації. У зв'язку з цим термін «візуальний» впроваджується у різні сфери життя людини, і освіта не є винятком. Відбувається оновлення поняттєво-термінологічного апарату, з'являються нові «візуальні» терміни освіти. Науковці майже завжди у своїх дослідженнях пропонують авторські варіанти формулювань 
цих понять, які не завжди аргументовані і узгоджуються одне з іншими. Тому аналіз таких категорії як «графічна культура», «інтелектуально-графічна культура», «візуальна культура» $є$ актуальним.

2. У науковій та методичні літературі спостерігається понятійний дисонанс: автори часто ототожнюють поняття «грамотність», «компетентність» та «культура» та дотримуються різного ієрархічного впорядкування цих понять. Вважаємо, що ланцюг «грамотність» - «освіченість» - «компетентність» - «культура» - «менталітет», запропонований Б. С. Гершунським найбільш точно відображає структурний ланцюг результативності освіти. Культура у такому контексті мислиться як вищий ступінь прояву людської освіченості, грамотності та компетентності.

3. Поняття «культура» в сучасній науковій літературі має надзвичайно велике число тлумачень. Різні науки надають різне змістове наповнення цьому поняттю. Але за різних трактувань поняття «культура» найбільш суттєвими рисами є: певний рівень досконалості в оволодінні діяльністю; глибоке, свідоме, поважне ставлення до спадщини минулого; володіння теоретичними знаннями, вміннями, навичками та готовність їх використання у практичній діяльності; здатність до творчого сприйняття та розуміння, творчого перетворення дійсності; готовність саморозвитку.

4. Графічна культура - це інтегративна якість особистості, яка характеризується високим рівнем сформованості графічних знань, умінь та навичок, готовністю використовувати їх у професійній діяльності, здатності відтворювати, зберігати та передавати графічними засобами різноманітну інформацію, передбачає здатність до аналізу, прогнозування, рефлексії професійної діяльності та забезпечує професійний творчий саморозвиток, самовдосконалення й підвищення фахового рівня.

5. Інтелектуально-графічна культура - це сукупність знань, умінь, цінностей та уявлень, що дозволяють не тільки засвоювати одиниці навчального матеріалу через наочно-образні (візуальні) моделі знань, а і самостійно їх проектувати, використовуючи в рівній мірі як логічні, так і художні можливості.

6. Візуальна культура $€$ категорією культурології. Педагогічні термінологічні словники не дають визначення візуальної культури, а педагоги-практики, використовуючи його для опису стану сучасного суспільства, посилаються на культурологічні дослідження. До того ж педагогічна наука до теперішнього часу не розглядала це поняття. Вектор пропонованого дослідження вимагає визначення візуальної культури як інтегративної якості особистості, яка характеризується високим рівнем візуальних знань, умінь та навичок (здатність сприймати, розпізнавати, аналізувати, інтерпретувати, оцінювати, співставляти, представляти та створювати власні візуальні образи), готовністю використовувати їх у професійній діяльності.

\section{Список використаних джерел}

1. Martin J. Downcast eyes: The denigration of vision in twentieth-century Frenchthought. Berkeley: University of California Press, 1993.

2. Paul B. Visual Culture Art Education: Why, What and How. Copyright NSEAD, 2002.

3. Rorty R. Metaphilosophical Difficulties of Linguistic Philosophy. The Linguistic Turn: Essays in Philosophical Method. Chicago: The University of Chicago Press, 1992. P. 1 -39.

4. Аранова С.В. Интеллектуально-графическая культура визуализации учебной информации в контексте модернизации общего образования. Педагогические науки. Вестник Челябинского государственного педагогического университета. 2017. № 5. С.9-16.

5. Аранова С.В. К методологии визуализации учебной информации. Интеграция художественного и логического. Вестник Адыгейского государственного университета. Серия 3: Педагогика и психология. 2011. № 2. С. 18-24.

6. Арнольдов А. И. Введение в культурологию. М.: НАКиОЦ, 1993. 349 с

7. Белоусова Л. И., Житенева Н.В. Дидактические аспекты использования технологий визуализации в учебном процессе общеобразовательной школы. Інформаційні технології і засоби навчання. 2014. Т. 40, № 2. С. 1-13

8. Брыкова Л. В. Формирование графической культуры будущего инженера. Ученые записки. Электронный научный журнал Курского государственного университета. 2011. №1(7). URL: https://cyberleninka.ru/article/n/formirovaniegraficheskoy-kultury-buduschego-inzhenera/. Дата звернення 15.12.2019.

9. Буянов П.Г. Формування графічної культури у майбутніх учителів трудового навчання України та Російської Федерації (порівняльний аналіз): автореф. дис. ... канд. пед. наук: 13.00.04. Київ, 2008. 22 с

10. Гершунский Б.С. Образовательно-педагогическая прогностика. Теория, методика, практика: учеб. пособие. М.: Флинта: Наука, 2003. 768 с.

11. Гомонюк О. М. Теоретичні та методичні основи формування професійно-педагогічної культури майбутніх соціальних педагогів у вищих навчальних заклада: дис. ... канд.пед.наук : 13.00.04 / Вінницький державний педагогічний університет імені Михайла Коцюбинськогою, 2012. 693с.

12. Гончаренко С. Український педагогічний словник. Київ: Либідь, 1997. 376 с.

13. Даль В.И. Толковый словарь живого великорусского языка: В 4 т. М.: Рус. яз., 1989.

14. Джеджула О.М. Шляхи розвитку графічної культури майбутніх фахівців інженерних спеціальностей. Сучасні інформаційні технології та інноваційні методики навчання в підготовці фрахівців: методологія, теорія, досвід, проблеми. 2018. №50. С. 261-265.

15. Дидактичні засади відбору і структурування змісту навчального предмета "Креслення" для професій металообробного профілю: метод. посібн. для професій металообробного профілю / Сидоренко В.К., Голіяд І.С., Кулик Є.В., та ін.; К., 2009. 351 с.

16. Друшляк М. Г. Словник візуальної освіти: наочність, візуалізація, візуальне мислення. Фізико-математична освіта. 2018. Вип. 1(15). Ч. 2. С. 78-83. URL: https://fmo-journal.fizmatsspu.sumy.ua/publ/4-1-0-499. Дата звернення 19.12.2019.

17. Друшляк М.Г. Словник «візуальної» освіти: графічна компетентність, візуальна компетентність. Фізико-математична освіта. 2019. Вип. 3(21). С.59-65. DOI 10.31110/2413-1571-2019-021-3-009.

18. Друшляк М.Г. Словник «візуальної» освіти: графічна грамотність, візуальна грамотність. Фізико-математична освіта. 2019. Вип. 2(20). Ч.2. С.34-45. 
19. Дубовая Н.В. Визуальная культура в аспекте современности. Тези доповідей III междунар. науч.-практ. конф. «Личность, семья и общество: вопросы педагогики и психологии». Новосибирск: СибАК, 2010.

20. Ефимов Ю. И., Громов И. А. Человеческий фактор и культура. Л.: Наука,1989. 192 с.

21. Зинченко В. П. Работа понимания. Психологическая наука и образование. 1998. №4. С. 17.

22. Зорин С. С., Веретенникова Л. К. Формирование визуальной культури. РИЦ ГГпИ Глазов, 2002. 188с.

23. Каган М.С. Философия культуры : учебное пособие для вузов. Спб. : Петрополис,1997. 205 с.

24. Коган Л.Н. Очерки социальной теории культуры. Свердловск, 1972. 169 с.

25. Кребер А. Культура: Критический анализ концепций и дефиниций. М. 1992.

26. Культура и культурология : словарь / сост. и ред. А.И. Кравченко. М.: Академич. Проект; Екатеринбург: Деловая книга, 2003. 928 с.

27. Курина В.А. Формирование графической культуры у будущих учителей технологии: дис. ... канд. пед. наук. Брянск, 1997. $232 \mathrm{c}$.

28. Лагунова М.В. Графическая культура инженера (основы теории): монография. Н. Новгород: Изд-во ВГИПИ, 2001. 251 c.

29. Лисюткин О. М. К вопросу о становлении категории «культура» (XVIII - начало XIX в.). Философские науки. 1982 . № 3. C. 24-27.

30. Лямина А. А. Формирование графической культуры у будущих конструкторов-модельеров в колледже : автореф.дис ... канд. пед. наук : 1300 08. Ставрополь, 2007. 26 с.

31. Мехоношина, О.В. Развитие визуальной культуры студентов художественно-педагогических специальностей при изучении искусства шрифта : дис. ... канд. пед. наук : 13.00 .08 / Ин-т худож. образования Рос. акад. образования. Москва, 2011. 174 с.

32. Моргун О. М. Визуальная культура невербальных коммуникаций в современной наружной рекламе : дис. ... канд. культурологии : 24.00.01 : Краснодар. гос. ун-т культуры и искусств. Краснодар, 2010. - 271 с.

33. Нищак І. Д. Інженерно-графічні знання, уміння та навички вчителя технологій: квінтесенція понять. Педагогічні науки, 2014, № 2 (66). С. 365-370

34. Нищак І.Д. Інженерно-графічна культура вчителя технологій як професійний феномен. Вісник Чернігівського національного педагогічного університету ім.Т.Г.Шевченка. 2015. С.186-188.

35. Новая философская энциклопедия : В 4 т. / Ин-т философии РАН, Нац. общ.-науч. фонд: научно-ред. совет: предс. В.С. Степин, заместители предс. А.А. Гусейнов, Г.Ю. Семигин, уч. секр. А.П. Огурцов. - М. : Мысль, 2001. Т.2. 634 с.

36. Потієнко В.О. З'ясування сутності поняття "художньо-графічна культура". Трудова підготовка в сучасній школі. 2012. № 11. С. 26-30.

37. Психологічна енциклопедія / упор. О. М. Степанов. К.: “Академвидав”, 2006. 424 с.

38. Социологический энциклопедический словарь. На русском, английском, немецком, французском и чешском языках / Ред. Г.В.Осипов. М. : Издателськая группа ИНФРА. М- НОРМА, 1998. 488 с.

39. Сырова Н. В., Чикишев В. Н. Визуальная культура как средство формирования общей и профессиональной культуры человека. Вестник Мининского университета. 2018. Том 6. № 1. С. 12-21.

40. Цицерон М.Г. Философские трактаты / Отв. ред. Г.Г. Майоров. М.: Наука, 1985. 381 с.

41. Чемоданова Т.В. Система информационно-технического обеспечения графической подготовки студентов технического вуза: дис. ... док. пед. наук: 13.00.08. Екатеринбург, 2004. 497 с.

42. Энциклопедический словарь / Под ред. Б.А. Введенского. М.: "БСЭ", 1954. Т. 2. 202с.

\section{References}

1. Aranova, S.V. (2011). K metodologii vizualizacii uchebnoj informacii. Integracija hudozhestvennogo i logicheskogo [To the methodology of visualization of educational information. Integration of the artistic and the logical]. Vestnik Adygejskogo gosudarstvennogo universiteta. Serija 3: Pedagogika i psihologija - Bulletin of the Adygea State University. Series 3: Pedagogy and Psychology. No 2. 18-24. [in Russian]

2. Aranova, S.V. (2017). Intellektual'no-graficheskaja kul'tura vizualizacii uchebnoj informacii v kontekste modernizacii obshhego obrazovanija [Intellectual and graphic culture of visualization of educational information in the context of modernization of general education.]. Pedagogicheskie nauki. Vestnik Cheljabinskogo gosudarstvennogo pedagogicheskogo universiteta Pedagogical sciences. Bulletin of the Chelyabinsk State Pedagogical University. No. 5. 9-16. [in Russian]

3. Arnol'dov, A. I. (1993). Vvedenie v kul'turologiju [Introduction to Cultural Studies]. M.: NAKiOC, 1993. 349 s. [in Russian]

4. Belousova, L. Y., \& Zhyteneva, N.V. (2014). Didakticheskie aspekty ispol'zovanija tehnologij vizualizacii v uchebnom processe obshheobrazovatel'noj shkoly [Didactic aspects of the use of visualization technologies in the educational process of a comprehensive school]. Informatsiini tekhnolohii i zasoby navchannia - Information technology and learning tools. Vol. 40, No 2. 1-13. [in Russian]

5. Brykova, L. V. (2011). Formirovanie graficheskoj kul'tury budushhego inzhenera [The formation of the graphic culture of the future engineer]. Uchenye zapiski. Jelektronnyj nauchnyj zhurnal Kurskogo gosudarstvennogo universiteta - Scientists notes. Electronic scientific journal of Kursk State University. No. 1(7). Retrieved from https://cyberleninka.ru/article/n/formirovaniegraficheskoy-kultury-buduschego-inzhenera/. [in Russian].

6. Buianov, P.H. (2008). Formuvannia hrafichnoi kultury u maibutnikh uchyteliv trudovoho navchannia Ukrainy ta Rosiiskoi Federatsii (porivnialnyi analiz) [Formation of graphic culture in future teachers of labor training of Ukraine and the Russian Federation (comparative analysis)]: Extended abstract of candidate's thesis. Kyiv [in Ukraine].

7. Chemodanova, T.V. (2004). Sistema informacionno-tehnicheskogo obespechenija graficheskoj podgotovki studentov tehnicheskogo vuza [The system of information and technical support for graphic training of students of a technical university]. Doctor's thesis. Ekaterinburg. 497 s. [in Russian]

8. Ciceron, M.G. (1985). Filosofskie traktaty [Philosophical treatises]. M.: Nauka. 381 s. [in Russian] 
9. Dal, V.I. (1989). Explanatory Dictionary of the Living Great Russian Language [Explanatory Dictionary of the Living Great Russian Language]: In 4 vols. M.: Rus. Yaz. [in Russian]

10. Drushliak, M. H. (2018). Slovnyk vizualnoi osvity: naochnist, vizualizatsiia, vizualne myslennia [Glossary of visual education: visualization, visualization, visual thinking]. Fizyko-matematychna osvita - Physical and mathematical education. Is. 1(15). P. 2. 78-83. Retrieves from https://fmo-journal.fizmatsspu.sumy.ua/publ/4-1-0-499. [in Ukraine]

11. Drushliak, M.H. (2019a). Slovnyk «vizualnoi» osvity: hrafichna kompetentnist, vizualna kompetentnist [Glossary of "visual" education: graphic competence, visual competence]. Fizyko-matematychna osvita - Physical and mathematical education. Is. 3(21).59-65. DOI 10.31110/2413-1571-2019-021-3-009. [in Ukraine]

12. Drushliak, M.H. (2019b). Slovnyk «vizualnoi» osvity: hrafichna hramotnist, vizualna hramotnist [Glossary of "visual" education: graphic literacy, visual literacy]. Fizyko-matematychna osvita - Physical and mathematical education. Is. 2(20). P.2. S.34-45. [in Ukraine]

13. Dubovaja, N.V. (2010). Vizual'naja kul'tura v aspekte sovremennosti [Visual culture in the aspect of modernity]. Proceedings of the III International conference «Person, family and society: issues of pedagogy and psychology». Novosibirsk: SibAK. [in Russian]

14. Dydaktychni zasady vidboru i strukturuvannia zmistu navchalnoho predmeta "Kreslennia" dlia profesii metaloobrobnoho profiliu: metod. posibn. dlia profesii metaloobrobnoho profiliu [Didactic principles for selecting and structuring the content of the Drawing subject for metalworking professions: a method. manual for professions of metalworking profile] (2009) / Sydorenko V.K., Holiiad I.S., Kulyk Ye.V., ta in.; K. 351 s. [in Ukraine].

15. Dzhedzhula, O. M. (2018). Shliakhy rozvytku hrafichnoi kultury maibutnikh fakhivtsiv inzhenernykh spetsialnostei [Ways of development of graphic culture of future specialists of engineering specialties]. Suchasni informatsiini tekhnolohii ta innovatsiini metodyky navchannia $v$ pidhotovtsi fakhivtsiv: metodolohiia, teoriia, dosvid, problemy - Modern information technologies and innovative teaching methods in the training of specialists: methodology, theory, experience, problems. No. 50. 261-265. [in Ukraine].

16. Efimov, Ju. I., Gromov, I. A. (1989). Chelovecheskij faktor i kul'tura [The human factor and culture]. L.: Nauka,1989. 192 s. [in Russian]

17. Gershunskij, B.S. (2003). Obrazovatel'no-pedagogicheskaja prognostika. Teorija, metodika, praktika: ucheb. Posobie [Educational and pedagogical forecasting. Theory, methodology, practice: textbook]. M.: Flinta: Nauka, 2003. 768 s. [in Russian]

18. Homoniuk, O. M. (2012). Teoretychni ta metodychni osnovy formuvannia profesiino-pedahohichnoi kultury maibutnikh sotsialnykh pedahohiv u vyshchykh navchalnykh zaklada [Theoretical and methodological bases of formation of professional and pedagogical culture of future social educators in higher educational establishments]: Candidate's thesis. Kyiv: Mikhail Kotsubinsky Vinnytsia State Pedagogical University [in Ukraine].

19. Honcharenko, S. (1997). Ukrainskyi pedahohichnyi slovnyk [Ukrainian Pedagogical Dictionary]. Kyiv: Lybid, 1997.376 s. [in Ukraine].

20. Kagan, M.S. (1997). Filosofija kul'tury : uchebnoe posobie dlja vuzov [Philosophy of Culture: a textbook for universities]. SPb. : Petropolis. 205 s. [in Russian]

21. Kogan, L.N. (1972). Ocherki social'noj teorii kul'tury [Essays on the social theory of culture]. Sverdlovsk, 1972.169 s. [in Russian]

22. Kravchenko, A.I. (Ed.) (2003). Kul'tura i kul'turologija : slovar' [Culture and Cultural Studies: Dictionary]. M.: Akademich. Proekt; Ekaterinburg: Delovaja kniga. 928 s. [in Russian]

23. Kreber, A. (1992). Kul'tura: Kriticheskij analiz koncepcij i definicij [Culture: A Critical Analysis of Concepts and Definitions]. [in Russian]

24. Kurina, V.A. (1997). Formirovanie graficheskoj kul'tury u budushhih uchitelej tehnologii [The formation of graphic culture in future technology teachers]. Candidate's thesis. Brjansk. 232 s. [in Russian]

25. Lagunova, M.V. (2001). Graficheskaja kul'tura inzhenera (osnovy teorii): monografija [Engineer's Graphic Culture (Fundamentals of Theory): Monograph]. N. Novgorod: Izd-vo VGIPI. 251 s. [in Russian]

26. Lisjutkin, O. M. (1982). K voprosu o stanovlenii kategorii «kul'tura» (XVIII - nachalo XIX v.) [To the question of the formation of the category "culture" (XVIII - beginning of XIX century.)]. Filosofskie nauki - Philosophical Sciences. No 3. S. 24-27. [in Russian]

27. Ljamina, A. A. (2007). Formirovanie graficheskoj kul'tury u budushhih konstruktorov-model'erov v kolledzhe [The formation of graphic culture in future designers-designers in college]: Extended abstract of candidate's thesis. Stavropol'. $26 \mathrm{~s}$. [in Russian]

28. Martin, J. (1993). Downcast eyes: The denigration of vision in twentieth-century Frenchthought. Berkeley: University of California Press. [in English]

29. Mehonoshina, O. V. (2011). Razvitie vizual'noj kul'tury studentov hudozhestvenno-pedagogicheskih special'nostej pri izuchenii iskusstva shrifta [The development of visual culture of students of artistic and pedagogical specialties in the study of font art]: Candidate's thesis. Moskva : In-t hudozh. obrazovanija Ros. akad. obrazovanija. 174 s. [in Russian]

30. Morgun, O. M. (2010). Vizual'naja kul'tura neverbal'nyh kommunikacij v sovremennoj naruzhnoj reklame [The visual culture of non-verbal communications in modern outdoor advertising]. Candidate's thesis. Krasnodar: Krasnodar. gos. un-t kul'tury $i$ iskusstv. $271 \mathrm{~s}$. [in Russian]

31. Nyshchak, I. D. (2014). Inzhenerno-hrafichni znannia, uminnia ta navychky vchytelia tekhnolohii: kvintesentsiia poniat [Graphic Engineering Knowledge, Skills of Technology Teachers: Notions Quintessence]. Pedahohichni nauky - Pedagogical Sciences, No 2 (66). 365-370. [in Ukranian]

32. Nyshchak, I.D. (2015). Inzhenerno-hrafichna kultura vchytelia tekhnolohii yak profesiinyi fenomen [Engineering-graphic culture of a technology teacher as a professional phenomenon]. Visnyk Chernihivskoho natsionalnoho pedahohichnoho universytetu im.T.H.Shevchenka - Bulletin of Shevchenko Chernihiv National Pedagogical University. 186-188. [in Ukranian] 
33. Osipov, G.V. (1998). Sociologicheskij jenciklopedicheskij slovar'. Na russkom, anglijskom, nemeckom, francuzskom i cheshskom jazykah [Sociological Encyclopedic Dictionary. In Russian, English, German, French and Czech]. M.: NORMA. 488 s. [in Russian]

34. Paul, B. (2002). Visual Culture Art Education: Why, What and How. Copyright NSEAD. [in English]

35. Potiienko, V.O. (2012). Ziasuvannia sutnosti poniattia "khudozhno-hrafichna kultura" [Understanding the concept of "graphic arts"]. Trudova pidhotovka v suchasnii shkoli - Work training in a modern school. No 11. 26-30. [in Ukranian]

36. Rorty, R. (1992). Metaphilosophical Difficulties of Linguistic Philosophy. The Linguistic Turn: Essays in Philosophical Method. Chicago: The University of Chicago Press. 1 -39. [in English]

37. Stepanov, O. M. (Ed.) (2006). Psykholohichna entsyklopediia [Psychological Encyclopedia]. K.: "Akademvydav". 424 s. [in Russian]

38. Stepin, V.S. (Ed.) (2001). Novaja filosofskaja jenciklopedija: V 4 t. [New Philosophical Encyclopedia] M. : Mysl'. Vol.2. 634 s. [in Russian]

39. Syrova, N. V. \& Chikishev, V. N. (2018). Vizual'naja kul'tura kak sredstvo formirovanija obshhej i professional'noj kul'tury cheloveka [Visual culture as a means of forming a common and professional human culture]. Vestnik Mininskogo universiteta - Bulletin of Minin University. Vol. 6. No 1. 12-21. [in Russian].

40. Vvedenskogo, B.A. (Ed.) (1954). Jenciklopedicheskij slovar' [Encyclopedic Dictionary]. M.: "BSJe". Vol. 2. 202s. [in Russian]

41. Zinchenko, V. P. (1998). Rabota ponimanija [A work of understanding]. Psihologicheskaja nauka i obrazovanie - Psychological Science and Education. No. 4. 17. [in Russian]

42. Zorin, S. S. \& Veretennikova, L. K. (2002). Formirovanie vizual'noj kul'turi [The formation of visual culture]. RIC GGPI Glazov. 188s. [in Russian]

\section{GLOSSARY OF “VISUAL” EDUCATION: GRAPHICAL CULTURE, VISUAL CULTURE Drushlyak M. G.}

Abstract.

Formulation of the problem. In the context of increased visual communication, a new culture of information perception is formed in modern society, mainly in the visual form. Increasing the visual component leads to the introduction of the term "visual" in the educational field. There is an update of its conceptual and terminological apparatus and there is a dissonance associated with the content of categories of "visual" education.

Materials and methods. Analysis of scientific and pedagogical sources to determine the content of the concepts of "graphic culture", "intellectualgraphic culture", "visual culture".

Results. Graphic and visual culture is a certain level of excellence in mastering an activity that is in one way or another related to different types of information: graphic (in the form of presentation) is information in the form of images, tables, diagrams, graphs, or visual (in the way perception) is information that is perceived by the eye. Graphic culture is an integrative quality of a person, characterized by a high level of graphic knowledge, skills, ability to use them in professional activity, ability to reproduce, store and transmit various information by graphic means, implies the ability to analyze, predict, reflect and provide professional creative self-development, selfimprovement and professional development. Intellectual-graphic culture is a collection of knowledge, skills, values and ideas that allow us not only to absorb units of educational material through visual models of knowledge, but also to design them independently, using equally logical and artistic opportunities. Visual culture is an integrative quality of a person characterized by a high level of visual knowledge, skills (ability to perceive, recognize, analyze, interpret, evaluate, contrast, represent and create their own visual images), willingness to use them in their professional activities.

Conclusions. The results of this study provide an opportunity with the content and correlation of the concepts of "graphic culture" and "visual culture", since the interpretation of these concepts in the scientific literature is heterogeneous and not always substantiated.

Keywords: glossary of "visual" education, culture, graphic culture, intellectual-graphic culture, visual culture. 